\title{
綜 說
}

\section{脺頭部切除について}

\section{Surgical Removal of Pancreas Head}

\section{福 田}

\section{I.はしがき}

䑏臟は後腹膜內にあり，その周囲には重要な る臟器や血管なとが密集し，特にその頭部は解 剖学的に極めて複雑な部分である。昔から膵尾 部や体部にわたる部分の切除が，比較的簡単に なされるのに反し，膵頭部の切除は容易に行わ れす，その切除は怑多の苦難の途をへて，迎年 渐くその成果が挙乩られるようになつた。

従つて以前は膉尾部などの悪性腫瘍やう氏島

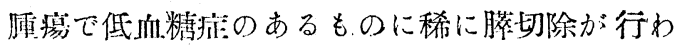
れ，また胃癌の滕浸㵎による部分的切除が，胃 切除に合併されて行われたに過ぎなかつた。と ころが近年は盥並に脾門部に及んだ噴門癌など に対しては，脾剔除と膵切除を合侀した胃切除 がそれ等を合併することにより却つて容易に なつた事実と共に, 膵頭部切除や蓃全剔出が進 んで行われるようになつた。これには廂猝の改 良や術前術啳の処置などが著しく進步したため に可能になつたものである。

\section{II. 櫒頭部切除の困難性}

既に述たように膵頭部切除は，解剖学的に完 全に根治的の切除をせんとすれば，血流の関係 もあつて十二指腸の大牛と胃とを其に切除し, 胆道や胃，膵や空腸などの断端処置をそれぞれ 考慮しなければならずままた菜から大動静脈,門 脈及び脾動静脈や上腸間膜動静脈などを分けて いくには，並々ならぬ苦心がいる。殊に癌性浸潤 などか膵頭部に密接している上腸間膜靜脈に及 んでいるか否かを知るには，手術操作を或程度 まですすめていつて，初めて明かになる場合が あるなと，他の部分の手術とは著しい相違と困

* 順天堂大学医学部外科学教室

1955 年 3 月 14 日受付

\section{Tamotsu FUKUDA*}

難性があつて，進めていつた手術を途中で中止 しなければならぬことが少くない。また膵頭部 周辺の操作には出血が多く，複雑な手術のため に手術時間も 3 時間から 5 6 時間もかかるのが 普通であるので，その閒の全出血量も多く 1000 〜2000ccにも澾することが稀ではない. 恐らく 現在行い得る手術中では，最も複雑した最も困 難な手術の一つであると言えよう。

膵頭部切除は㼛に 50 余年前 Codivilla(1898) が行つた記錄があるが，手術後 24 日で死しし ている. Kaush (1909) の例は乳頭部癌であつ て、これを膵頭部と共に切除し，数分月の生命 を保つことが出来だが，現在のような膵頭部切 除の成功例は 1953 年 Whipple 等の翢告したる のが初めてであるようである。

\section{III. 手術の適應}

本手術の適応としては, 膵頭部, 胆道下部, Vater 乳頭部なとの癌腫や, 十二指腸などよ 発生した肉腫などの，主として膵頭部に関係し た悪性腸瘍が対象となる。いづれにしてる困難 なる手術である上に，適度のある患者の大部分 が黄㾝に脳まされ, 肝障害を伴い血液凝国性が 低下して，出血性素質があるために，現在では ビタそンKやその他の準備によつて或程度防が れるにしても，大手術には不向きの悪条件があ るので，汃る手術の行われた初期には手沺の 直接死亡゙率が 30-40\%以上にも及んだが，現在

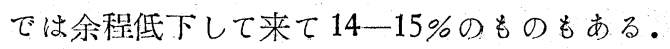
いづれにしても適応をよく教虙しよく準備を施 さない以上，手術死をなくすることは不可能で あ万弓・しかもその手術成績特にその遠隔成績 の悲観的であること考考え，また膵臟の切除や 全剔出により，膵藏の队外分泌障害なとの点 
で, 現在に於ける本手術の価值㛐に検討を要 するものと思われる。

米国などでは本手術成功の歷史は20 年に及 ぶが, 本邦では約十数年後れて炤和 24 年吕岡 氏の報告以来，汃る手術例の翢告は佮僅か で, 梶谷, 本压, 大野, 桂の諸氏の例があり。 吾々も東京大学在職中, その4例走報告し, 現 在までに順天堂大学外科に於て, 更に 4 例走加 えるに至つたので，これ等についての手術例を 一応検討してみることにする。

\section{IV. 症 例}

既に報告した 4 例は膵頭部癌 1 例，十二指腸 より発生したと認められる癌 1 例, Vater 氏乳 頭部癌 1 例と十二指腸毠室の診断で開腹し, 十 二指腸の櫒頭部に面した腸壁に潰瘍を作つた肉 腫の 1 例であつた。癌腫の例中 2 例は退院後 3 ケ月刀至 1 年数分月で死ししたことが判明して いるが，乳頭部癌と闪腫の例は最近まで生存し ている等である。然しここの2例は手逨所見か ら見て根治の見达みの高いものであつた。後半 順天堂大学に於ける4例の概要は次の如くで ある。

\section{(1) 第1 例（図 1)}

59 才，男. 主訴としては黄疸と灰白色便, 約 1 年前より背部鈍痛があり, 腹部膨満感, 便 秘, 食慾不振, 倦急感があり, 好きな酒も飲め なくなつた。昭和 27 年 11 月頃黄疸を生し，其

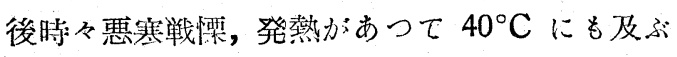
ことがあつたが、間もなく本熟となり，気分も 本常と変りがなようになつた。

入院後の所見では, 黄疸强く, 腹部は右助骨 弓下に比較的広い範困に抵抗を触れるのみで, 著しい所見はない。背部の痛みは低然として去 らす，両局胛部に放散する。贫血や白血球䝬多 もなく，尿は時々蛋白を証し糖はない，便は灰 白色不渻化で, 血清, モイレングラハト150, ヂアスターゼ $\mathrm{d} \frac{30^{\prime}}{38^{\circ}}=8$, ヘパトサルフフレン 肝機能検查では30 分 $15 \%$ ，45 分で 10\%, GB 1053, GP 1023.

胆装炎の疑で開腹すると, 胆汁流出を見た
が，第孔を見出し得す，数日前 needlebiopsy を行つているので, 恐らく楞滯した肝の穿刺部 からの漏出と想像された。膵頭部に指頭大の硬 い腫癌を認め，結石でないことを確めたか，手 術準備が立分でないので，ます胆囊胃吻合にと どめて、腹腔を閉じ次の機会を待つことにした。 黃洹も急速に軽快し, 術後 19 日目充分の準 借をととのえた上で,第2次手獄を試みた。困難 な手術ではあつたが, 胃十二指腸膵切除を行 い, 手術時間 3 時間牛, 出血量 $1700 \mathrm{cc}$, 輸血. $1000 \mathrm{cc}$, 其他水分补給を行い, 手術を完了した。 術後多少の困難もあつたか;, 漸次回復して, 第 2 次手術後 24 日で退院した。

図1. 第 1 例

a. 第 1 次手術（胆囊胃吻合）

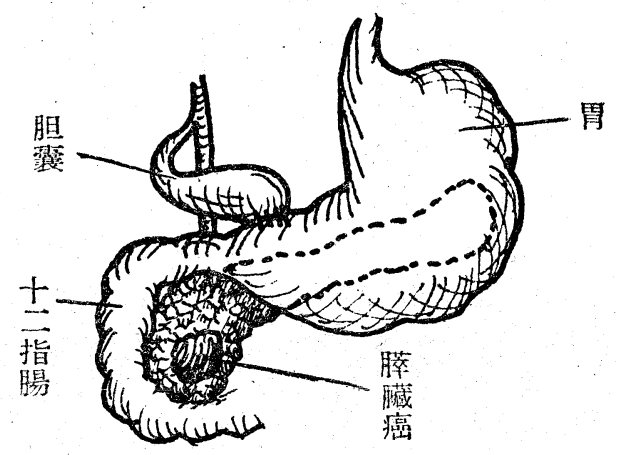

b. 第 2 次手術（膵頭部初除）

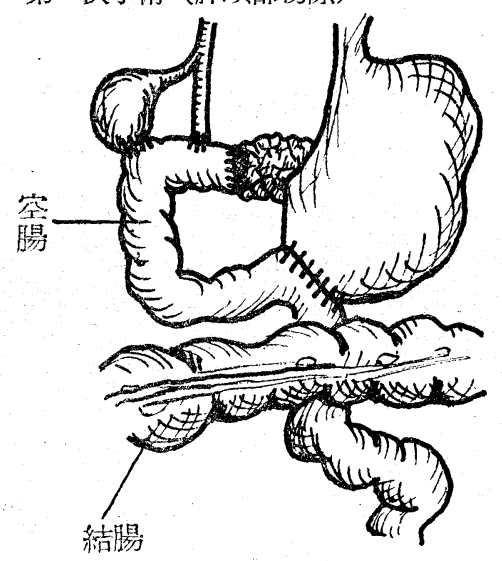

切除標本によると, 胆管梀端部より乳頭に及 ふ円杜上皮腺癌であつた。その後外来に時々通 つていて, 往々背部痛に惱まされていた。手術 後1年7ケ月で死ししたことか゚かかな。 
(2) 第 2 例 (図 2)

67 才, 男. 主訴㤨㨁で, 昭和 28 年 5 月牛 ば, 突然悪寒高熱 $40 \circ \mathrm{C} に$ 及んだ。黄渲のある ことに注意され，医療を要けていたが好転せず 入院加療することになつた。

図 2 第 2 例

a. 第 1 次手術（胆霔空腸勿合）

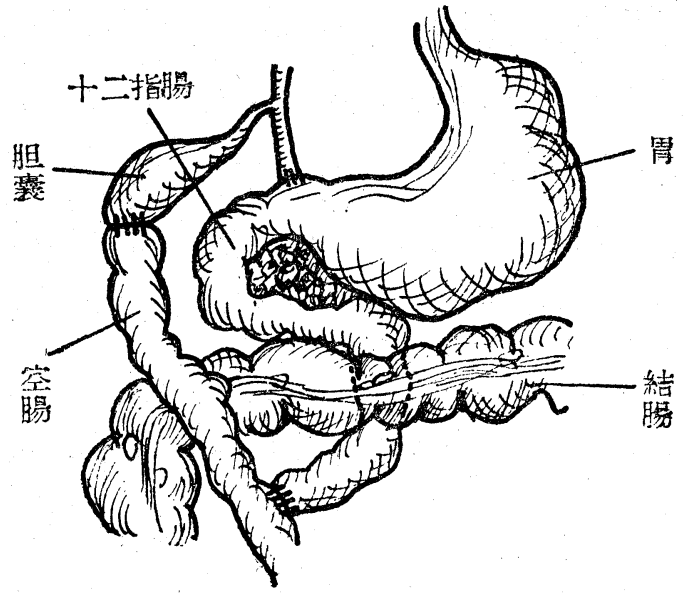

b. 第 2 次手術（膵頭部切除）

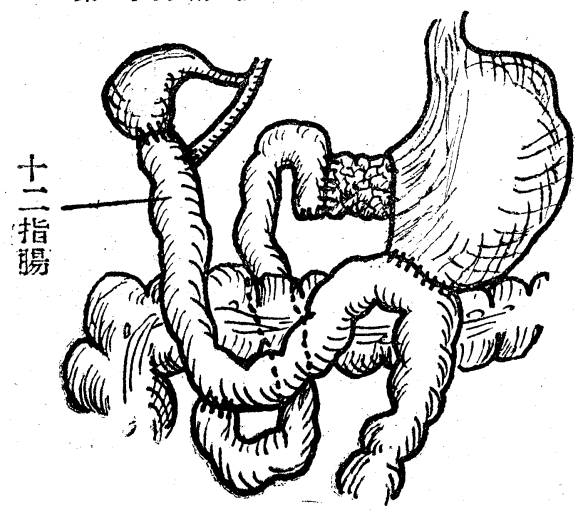

黄渲甚しく腹部膨満し, 肝藏總は右肋骨弓下4 横指, 胆㐮肥大を触れ压痛はない。足背には浮 腫を見る。血圧高く 205-90, 赤血球 300 万,白 血球 5100, GB 1049, GP 1022. モイレングラハ r. 80, 尿中蛋白 $(-)$, 糖 $(+)$, 潜出血を証し, 旰機能障害も著明であつた。

膵頭部癌の疑で, 黃疸の発生を見てから 5 ケ 月後に，ま吉第一次手術により，胆表空晹吻合 を Roux 氏 $\mathrm{Y}$ 字型吻合によつて行つた。旰臟
や胆装灿肥大し，結石を証明せす，櫒頭部に硬

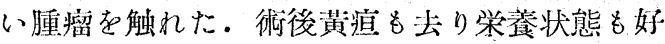
転し，潐供がととのつた上で，第 1 次手術後 34 日目に根治的膵切除を行つた。

手術時間 3 時澗15分, 出血量 $687 \mathrm{~g}$. 輸血 $600 \mathrm{cc}$ 其他榆液を施した。手術後嗔気, 㗐吐はげし

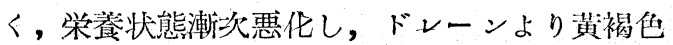
具全ある排液多量に及び，肺水腫などを起し， 第 2 次手術後 18 日目に死亡した。

\section{(3) 第 3 例 (図 3)}

48 才，女，主訴は上腹部痛で，10 年程前よ り年 2 回程，上腹部痛があり注射でとめてい た。昭和 28 年 8 月初めに同様の発作があり,

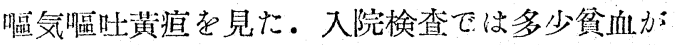
あり，白血球增多はない,尿中蛋白 $(+)$ 糖 $($ ( ) , 血清モイレングラハト 145, 胆珵炎として開腹 した。膵頭部に硬い結笁を触れ，二三のリンパ 腺腫脹も認ぬた。悪性:のもの老疑い, 膵頭部切 除を行つた。手少封間 3 時間, 出血量 $938 \mathrm{~g}$. 輸血 $700 \mathrm{cc}$ ，デキストラン $500 \mathrm{cc}$ 其他輸液を㧈 光術後経過良好 1 ケ月牛で退院. 現在 1 作 7 ケ 月になるが異常はない。切除標本の硬結部には 癖組織を発見しえす，炎拝性の硬結であつた。

図 3 第 3 例

1 次的膵頭切除

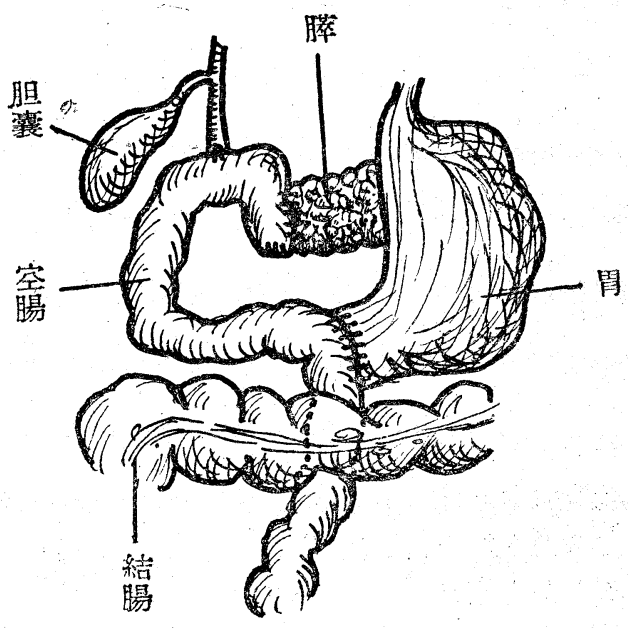

（4）第 4 例 (図 4)

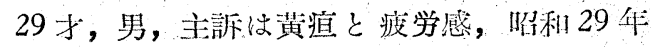


10 月頃，全身疼労感と黄疸を認めるようにな り，発熱，腹痛，政符などはなく，出勤しなが ら治療老受けつつあつた。12月初めには右肋 骨弓下に鈍痛を覚气，便怯灰白色となり，皮膚 に搔㾕感があつた。大院後は黄湿は誢しく，肝 藏仙右肋骨弓下 3 橫指まで腫脹し, 多少の压痛 がある。貧血も白血球增多もなく，モイレング ラ八ト 28 , 尿に法璜㾝尿の外には特記すべも

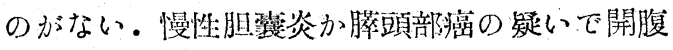
した。

図 4 第 4 例

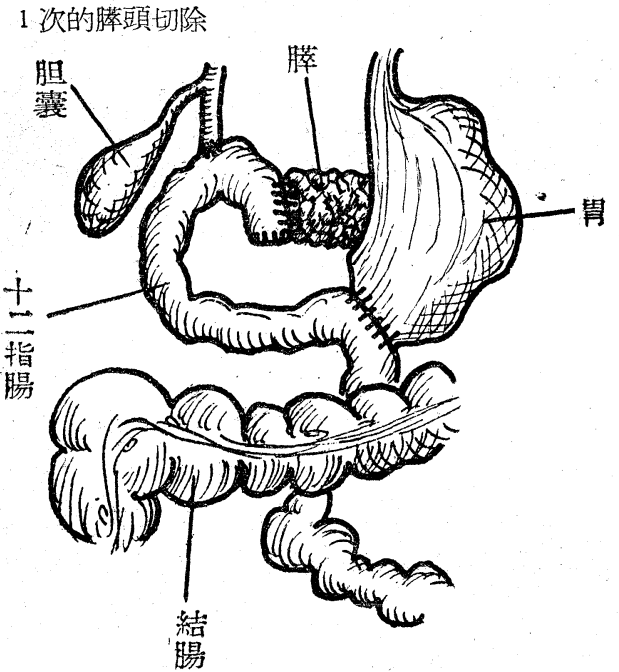

腹水なく肝臟は暗綠色著しく肥大し，胆謷も 著しく拡張している。膵頭部に鳩卯大の腫瘤を 触れ硬く，切除の見达みもついたので，根治手 術を型の如く玄めた。最後の殷階になつて， 上腸間膜静脈壁の一部に癌浸㵎のあることを認 めたが，靜脈壁の浸潤部を止むを得か残して切 除し，困難な手術を完了した。出血量 $1100 \mathrm{cc}$ 以上, 輸血. $2800 \mathrm{ce}$, 手術時間 4 時間本であつ た。術後経過順調で, 本手術時重琶な腹腔內ド レーンの插入を行わすに閉じてしまつたので， 抗生物質を充分に用い警武していたが無事経過 して食慈も進み，術後20日で元気よく退院す ることが出来た。

\section{V. 症狀と診㫁について}

胆道未端部及び十二指腸乳頭部 (Vater)の 癌や，その附近の膵頭部及び十二指腸壁より生

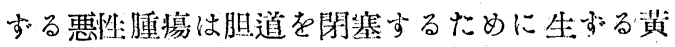
㾞によつて，その症状の重姴なる部分汃比較的 早期に現れる。然し滥疸を生する疾患は多数あ るので, 黃渲の種類やその性状についての区別 を明かにすることが大切である。胆道閉塞によ つて腸內に胆汁が出なくなると瓷便は胆汁色を 失い灰白色になり，脂肪の渻化が障害される のて，脂肪便や不消化便を見るようになる．然 し胆道閉塞牥結石や炎症性般痕でも生すること があるし、外部よりの压迫でも起り得るもので ある。

悪州腫場による閉塞は進行性であるので, 黄 㾞は潮炏進行して黄疸は徐々に悪化するばかり であるし，時に上行感染で胆道炎を起し発熱す ることもあるが，結不の昜合に比して少いし， 結石の望合と異り所謂結石疝痛やその以前に腹 部痛のあつた既往を欠いていることである。ま

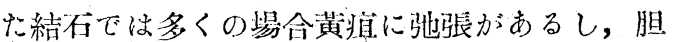

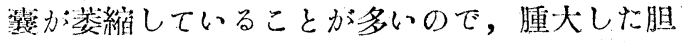

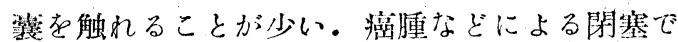
は, 胆琶には病変がないので, 胆汁は胆装に无 満して大きくなつた胆瑟として触れる。所謂 Courvoisier 䇥状か陽性となる。老人でこのよ うな姃状が多少でもあれば，時を移さすに開腹 することをすすめたいわけである。後に述べる ように本手術は早期稆楽であるし，また一寸進 行すると手術は益々困難となるばかりでなく根 治手術の時期を失うからである。つまり症状が 此較的早く現れるから，それを捕えて早く手術 に向ける用意をすることが大切である。

\section{VI 考察及び批判}

以上は手術操作の観点から，早期の診断を必 要とするものであるが，かかる閉塞性黄疽を経 過するうちに，肝機能は漸次低下し，血液薙固 性が減退するので，いづれにしても手術には琶 条件が增加して来る。既に述べたように，出血 にしても手術時間にしても極めて多く，現在大 手䢖中での主位を占めるものであるので，惡条 件の下に侵襲の大なる手術を行うことになる。 手術操作については勿論, その前後処置につい ても積極的手段を必要とする。昔加黄瘨と灰 
白便の発現があつて，2週間或は 3 週間以上経 過するものでは，手術の伦険があると言われて いた．今日では手術準䟮として輸血の外にビタ えン B, C, K 在与光るとか, 其他の栄養补給 を充分に行って，孯条件を改善することが出来 るが，症例に見るように発病して手術までに相 当の時期を経過している場合が少くないので， 手術の困難は想像に余りあると思う。つまりか かる疾患の多くは全身的に，大手術に対し不向 さの状態にあるので, 手術準備としては余程の

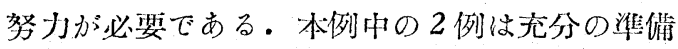
もなしに，しかも黄渲を発して長期間を経ての 手術であるので，ます黃㾝を去るような手衡に より状態を好転せしめて，2炏的に切除を行わ ねばならぬことになつたわけである。

手術そのものの困難は度々述心゙た通りである がま少膵頭部周囲の解剖をよく心得て置くこ

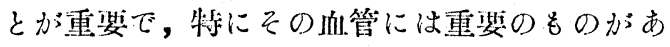
るし，その相互の血管やその枝が極めて複雑で あることが，操作を困難にさせる。まず十二指 腸外緣の腹膜者切開して, 指頭を以て十二指腸 外壁を剩離していくと，その後方に大靜脈力゙現 れ，更に進むと膵頭部後面に大動脈を触れる。膵 後面を静かに鈎状突起までも荆離してみて，腫 熘に移動性があるようであれば，根治手術の第 一の見通しがついたわけである。次で横行結腸 間膜の根部でトライッ氏墐帶の上方の腹膜を橫 に切開して，十二指腸未端部を遊離しつつ進む と膵鈎状突起後面に出るので, 膵頭部と十二指 腸末端部との間を走る上腸間膜動静脈を分離す るのであるが，この際上腸間膜静脈に膵頭部癌 がよく浸潤していることがあるので，これを確 め浸潤していることがわかればここで根治手 術を断念しなければならないここに癌着がな けれぼ，根治手術の第2 目標である見通しがつ いたわけである。

次に胃幽門部を一時切断するのであるが，胃 の $1 / 2$ 程の部分でます胃を橫に切断し，次て膵 藏下緣の腹膜を切開し, 鈍性に膵後面を剚離し 膵上緣からも同様にして剥離し, 後面を遊離し 適当な部位で膵を切断する。断端は結節逢合で

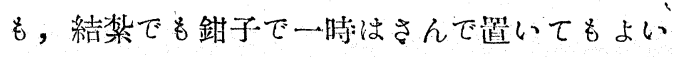
が，この際脾静脈に注意し,幽門部断端と膵頭部 断端と委眽転しながら，菜頭部後面を血管から 遊離していき，最後に上腸間膜靜脈の僅かな部 分ではあるが, 今迄の操作で澾し得なかつた部 分に，癌の浸潤があるか否やを確めることにな る・この静脈の僅かな部分に浸潤があつたり， 血栓のあることがあるのでその場合には根治手 術を断念して，胃は両切断端を逢合して元に疛 し，膵尾部は残して置くと危険性があるので切 除し，頭側断端を縫合閉鎖して，手術を中止し なければならない。この部分の上腸間膜静脈を 結紮切除してもよいと言う者もあるし，切除し て血管移植をすることも今挠の問題とはなろう が,現階段では止むを得ないこのの部分は山血も 多く，第 4 例では，手術がここまで進行し，士 晹閒膜靜脈に涭潤を認め血检を触れたのて，手 術を中止すべきではあつたが，止むを得ず僅か な部分の浸潤老残して切除したので，この点で 根治手術にはならなかつた。目下入院中で万一 組織学的所見が良性のものであれば幸芯ある が，今のところ患者は至極元気であり，近日中 退院準備中である。

次に問題となるのは切除断端処置の複雑なこ とである，胃十二指腸膵頭部を切除する上は， その断端をそれぞれ調製されなければならな い. 少くる3つの吻合を必要とし, 上行性感染 を防ぐために胃空腸吻合は最下部に施し，他の 空腸胆道吻合や腸膵管吻合は，その上部につけ るのが有利とされている, 後者 2 つの吻合性技 術的に問題の多い所であつて, 吻合部は胃空腸 吻合の如く確実が少く，一時洩れる恐れもある ので, 腹腔內ドレーン插入と感染防止が, 本手 術の成切には相等重要性を占めて居り抗生物筫 を充分に用い，栄養を高的て組織の再生再建を 早める必要があるし，吻論手術侵襲が大である ので, ショックの手当や術後栄養補給の問題も 特に努力を必要とし, その成果如何を手術の死 亡率を充分に左右し得るものと思う。

\section{VII. 將來の問題}

既に述べたように手術の死亡率は減少して来 
たものの，乎術患者の全身状態，手術侵襲の過大 などにより，術後の処置を余程强力にしない以 上死亡率を無にすることは困難である。また遠 隔成績は現在のところ,多くは悲観的であるが， これは各部面からの進步により向上の見达みも あり早期診断と早期手術により将来性を待つわ けである・次で術後の機能については引きつづ き膵切除後の消化機能や內分泌障害が検討さ れ，脂肋肺などの発生が奬念されている・膵全 剔除の際には相当問題が起るようであるが，滕 頭部切除のみでは內分泌機能に法変化は少い し，外分泌㵏管を空腸に移植することにより その機能障害は余程防がれるようである。遠隔 成樍による機能障害が残されるや各やは倘明か ではないが，生物の順応性により多少の失調は 潮炏調節されていくことを予想しているわけで ある。

\section{VIII. むす び}

畹唡卒等の進步々術前術後の体內代謝調節の如 们によつて, 従来殆んど不可能に近い膵頭切除 が可能になつた。その死亡率も漸次向転して， 膵頭部や十二指腸胆道の悪性腫場に対しては， 従来只胆湮，胃または十二指腸吻合が唯一の手 衍法で，単に生命を延長するに過ぎなかつたの
か，本手術により根治の見达みの立つたこと 怔，近年の進步であり，份その手術法や術前術 挠処置には改良すべき点もあり，また遠隔成䋶 も悲観的ではあるが，早期診断と手術の時期を 早めることにより，成績は向上するものと思 う.術後の機能障害は少くも櫒頭部に限局する ものでは，奬念がないものと信する炏第であ る・

\section{主なる交献}

1) Bier-Braum-Kümmell : Chirurgische Operationslehre (1923)

2) Whipple, A., Parsons, W. \& Mullius, C.: Ann. Surg., 102, 763 (1935)

3) Whipple, A. O.: Surg. Gynec. \& Obst., 82623 (1946)

4) Child, G. G. III.: Ann. Surg. 118, 838, (1943), 119, 845 (1944)

5) Dragstedt,L. R. : J.A.M. A., 11429 (1940)

6) 本庄：外科, 12, 129 (1950)

7) 吉岡: 臨物外科, 7, (11), 607 (1952)

8) 吉岡: 手術, 5 , (10) 511 (1951) 5, (11), 575 (1951)

9) 福田：手術, 6, (7), 376 (1952)

10) 桂, 鈴木：外科, 13, 121 (1952)

11) 福田：最新医学, 8, (1), 53 (1953)

\section{Summary}

Due to the progress in anesthesiology and with the control of body metabolism pre- and postoperatively, surgical removal of the pancreas head which has hitherto been regarded as nearly impossible has become a possibility.

The death rate due to this condition has gradually decreased and where, until recently gallbladder, stomach or duodenalanastomosis was the only operative method and was performed only to prolong life, the fact that chanses of permanent cure may be obtained through this operation is a progress of recent years. Although there are still points for improvement in operation procedures and in pre- and postoperative treatments and the long term evaluation presents a pessimistic view, an opinion is held that early diagnosis and early operation would improve the results. It is believed that there is no fear of functional disturbances post-operatively at least in those cases localized in the head of pancreas.

Dept. of Surgery, Faculty of Med., Juntendo University. 